\title{
Skull morphometric characters in parrots (Psittaciformes)
}

\author{
Tibor PeCsics ${ }^{1 *}$, Miklós Laczi ${ }^{1,3}$, Gergely NagY ${ }^{1}$, Tamás KondoR ${ }^{1}$ \\ \& Tibor CsÖRGÖ ${ }^{2}$
}

Received: April 24, 2020 - Revised: June 02, 2020 - Accepted: June 03, 2020

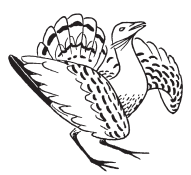

Pecsics, T., Laczi, M., Nagy, G., Kondor, T. \& Csörgő, T. 2020. Skull morphometric characters in parrots (Psittaciformes). - Ornis Hungarica 28(1): 104-120. DOI: 10.2478/orhu-2020-0008 cies of parrots are largely or exclusively arboreal with several exceptions. The species also differ in diet and habitat, which led to different musculoskeletal adaptations of the skull. However, parrots have conspicuous generalized external features; in this recent study, we tried to increase our knowledge of the cranial shape and foraging habits. A geometric morphometric approach was used to analyse two-dimensional cranial landmarks. We used principal component (PC) analyses on measurements that may be related to diet. The PCs described the relative height of the cranium, the relative length and curvature of the beak, differences in the orientation and curvature of the lacrimal bone and the upper margin of orbits, variation in the size and position of the palatine bone and the relative width of the cranium, and variation in the relative size of the neurocranium compared to the viscerocranium. The dietary categories overlap in the morphospace but the analysis in lateral and ventral view resulted in significant differences.

Keywords: cranial morphology, morphometrics, anatomy, jaw, skull, shape, convergent evolution, parrot, diet preference, bill shape

Összefoglalás A papagájalakúak rendje (Psittaciformes) egyedi és jól elkülöníthető madárcsoport, amelybe méretükben és színezetükben rendkívül változatos fajok tartoznak. Néhány kivételtől eltekintve a fajok többsége trópusi, illetve szubtrópusi erdőkben és ligetekben található. Az egyes fajok különböznek méretükben és táplálékpreferenciájuk tekintetében, ennek megfelelő eltéréseket mutatnak koponyájuk csontozatában és izomzatában. Habár a papagájok jól megfigyelhetö egyetemes tulajdonságokat mutatnak, jelen vizsgálatunkban a cranialis jegyek és a táplálékpreferencia közötti lehetséges kapcsolatokat kerestük. A geometriai morfometriai vizsgálat során kétdimenziós landmarkok használatával főkomponens-analíziseket végeztünk. A fökomponensek a koponya relatív magasságát, a csör relatív hosszúságát és görbületét, a könnycsont relatív helyzetét és a szemüreg felső részének ívét, a szájpadcsont viszonylagos helyzetét és nagyságát, valamint az agykoponya és az arckoponya egymáshoz viszonyított nagyságát mutatják. Az egyes táplálkozási csoportok átfednek egymással, azonban a vizsgálatok oldal- és alulnézetben észrevehetö különbségeket mutattak.

Kulcsszavak: koponyasajátosságok, morfometria, anatómia, állkapocs, koponya, alak, konvergens evolúció, papagáj, táplálékpreferencia, csőrforma

${ }^{1}$ Behavioural Ecology Group, Department of Systematic Zoology and Ecology, Eötvös Loránd University, 1117 Budapest, Pázmány Péter sétány 1/C, Hungary

${ }^{2}$ Department of Anatomy, Cell- and Developmental Biology, Eötvös Loránd University, 1117 Budapest, Pázmány Péter sétány $1 / C$, Hungary

${ }^{3}$ The Barn Owl Foundation, 8744 Orosztony, Temesvári út 8., Hungary

*corresponding author, e-mail: nobilis.equus@gmail.com 


\section{Introduction}

Parrots (Psittaciformes) are a unique and diverse group of birds. The species vary tremendously in size, shape, and colour. Although there is an extraordinary degree of variation in their external appearance, parrots are one of the most easily recognisable birds due to their conspicuous external features. Prominent and obvious characteristics include the strong curved bill, fleshy cere, proportionately large, broad head, and zygodactyl feet (Forshaw 2010). The parrots are mainly distributed throughout the tropics and subtropics and most species are largely or exclusively arboreal, but there are exceptions. Some species are exclusively terrestrial, inhabit grasslands, or prefer alpine vegetation (Bryant 1994).

This large and diverse order is traditionally classified into four families: Nestoridae (New Zealand parrots), Cacatuidae (cockatoos), Psittacidae (African and NewWorld parrots) and Psittaculidae (Old World parrots) (Christidis \& Boles 2008, Hackett et al. 2008, Mayr 2010, Jarvis et al. 2014, Prum et al. 2015, Provost et al. 2017). The order contains over 390 species in 74 genera and most of the species are concentrated in the tropical and subtropical regions of the Southern Hemisphere (Barker et al. 2004, Homberger 2006, McCormack et al. 2013). Diversity in South America and Australasia suggests that the order may have evolved in Gondwana during the Cretaceous period (Cracraft 1973, Barker et al. 2004, Cracraft et al. 2004, Forshaw 2010). The few early fossils that have been discovered do not have modern parrot-like cranial morphology (Mayr et al. 2013). However, parrots possibly evolved in Gondwana; early psittaciform remains have mainly been found in the northern hemisphere and fossil evidence of a stem group in Europe concludes that there was diversification following the Mesozoic era (Dyke \& Mayr 1999, Waterhouse 2006).

Parrots are the focus of an increasing number of studies in such areas as vocal communication (Bradbury 2003), brain evolution (Iwaniuk et al. 2005, Carril et al. 2016) and craniofacial morphology (Tokita 2006, Tokita \& Nakayama 2014).

These birds developed novel cranial morphology and show considerable morphological diversity in the cranial musculoskeletal system. This includes two novel structures: the suborbital arch and the musculus pseudomasseter (Tokita 2003, Tokita et al. 2007). A previous study in geometric morphometric work explored the relationship among skull shape and ecology, which reflected the size and structure of the jaw muscles. Parrots are characterised by their large beaks and are renowned for their ability to produce high bite forces. Factors that influenced the evolution of psittaciform birds' distinctive cranial morphologies were tested (Bright et al. 2019).

Although the fundamental pattern of the skull development of birds is conserved in parrots, some differences were observed between parrots and other avian orders. In parrots, the vacuity in the interorbital septum did not emerge throughout ontogeny. This feature is referring to the attachment of the unique jaw muscle at interorbital septum, musculus ethmomandibularis. In parrots, the cranio-facial hinge was brought about by secondary transformation of dermal bones. In other groups of birds with a standard prokinetic skull, the nasal-frontal suture directly becomes a hinge of bending. The parrot-specific structures like suborbital arch and cranio-facial hinge are not seen until the juvenile birds leave the nest and can feed alone. These structures are necessary for eating tough food material (Tokita 2003). 
Parrots occupy varied dietary niches that require an agile, mobilized, but sturdy feeding apparatus. Cranial kinesis, or the flexibility of intracranial joints, has a central role in the unique feeding apparatus (Cost et al. 2017).

Neotropical parrots are ecologically important because of their role as seed eaters and the impact on the structure of tropical forests (Janzen 1969, Terborgh et al. 1990, Galetti \& Rodrigues 1992). Neotropical species usually forage for nectar, flowers, leaves, fruit pulp, and seeds. Due to the mosaics of the vegetation, these birds use the abundantly available resources. Smaller and larger species foraged on fruits; parakeets largely consumed the pulp, while larger parrot species used pulp and seeds (Ragusa-Netto \& Fecchio 2006).

The diversity in morphology, body size, and foraging behaviour are in relation to diet and geographical range. Parrots are granivores rather than seed dispersers and in many cases where they are seen consuming fruit, they are only eating the fruit to get at the seed. The seeds often have poisons or toxins; therefore, the parrots carefully remove coats of the seed. Geographical range and body size explain diet composition rather than phylogeny (Benavidez et al. 2018).

The foraging performance and the cranial morphology are functionally linked to numerous vertebrate taxa (Dumont 2003, Anderson et al. 2008). The feeding system of most vertebrates produces bite force by the musculoskeletal system of the head (Herrel et al. 2005). The feeding methods provide an example of the link between morphological modification and performance (Benkman 2003). Numerous vertebrate taxa show that cranial attributes are related to bite force (Csermely et al. 1998, Ward et al. 2002, McBrayer 2004, Van der Meij \& Bout 2004, Anderson et al. 2008, Sustaita \& Hertel 2010).

The feeding strategies are highly diverse and the morphological adaptations for feeding are a notable feature of avian evolution (Zweers et al. 1994). The avian skull shows a great variety of morphological variation (Zusi 1993). Allometry possibly has a key role in craniofacial form across a range of avian orders (Colwell 2006, Marugán-Lobón \& Buscalioni 2006, Kulemeyer et al. 2009, Fabbri et al. 2017).

Most of the parrot species are omnivorous (Lill 2009) and opportunistic when presented with new feeding opportunities, but sometimes also feed on plants and insects (Clarke 1971, Brejaart 1988).

Lories, lorikeets, hanging parrots, and swift parrots are primarily nectar and pollen consumers. Specialization to nectarivory is associated with radiations within different bird groups. Their shift to nectarivory may have created an ecological opportunity that promotes species proliferation and radiation. Morphological specializations of the feeding apparatus to nectarivory have been described for parrots (Schweizer et al. 2014).

Some other examples are more extraordinary than nectarivore species. Pigmy parrots (Micropsitta spp.) are suspected to rely heavily on fungi and lichens for food (Rand 1942, Elliott et al. 2019). Kea have been reported feeding on chicks and eggs (Temple 1996), mice (Beggs \& Mankelow 2002), and domesticated sheep (Marriner 1908) and carrion (Edgar 1974).

The morphology of the skull, the maxillary and mandibular characteristics, and the important details of the skull structure are determinants of the different foraging groups. The 
two dimensional methods allow size and shape to be considered independently, preserve geometric information, and offer techniques for studying in form (Adams et al. 2004).

In this preliminary study, we investigated the cranial and morphological diversity among the different groups. Our objective was to increase our knowledge on the relationship between skull shape and the foraging habits of parrots and possibly find those characteristics that are related to diet and foraging habits. We also tried to find the convergent attributes. The differences in force acting on the beak during feeding may be related to skull geometry and jaw muscles. The significant overlap in skull geometry between the species would suggest that skull geometry has evolved along similar pathways. Differences may reflect selection pressures related to the different foraging habits and mechanical demands. To investigate the morphological diversity of the skulls, we used landmark-based morphometric methods.

\section{Materials and methods}

\section{Specimens}

This study is based on 150 skulls of 108 species. All skulls are from adult specimens of parrots and belong to the collection of Eötvös Loránd University (Budapest, Hungary), the collection of the Hungarian Natural History Museum (Budapest, Hungary), and the digital archives of Wageningen University (Wageningen, Netherlands). No bird has been killed to obtain its skull; all birds died either of natural causes, whether accidental death or whether it died in captivity.

\section{Groups and diet}

This study seeks to test that the different diet and foraging method may have an effect on skull morphology. Before the analyses, we created five groups which represent the following diet categories (Pizo et al. 1995, Perrin 2009, Lee et al. 2014).

- A: Nectarine, soft food item eaters (Schweizer et al. 2014)

- B: Predominantly seed eaters (Boyes \& Perrin 2009)

- C: Big and rough food item eaters (Wood 1988, Vaughan et al. 2006)

- D: Generalists (McInnes \& Carne 1978, Brejaart 1988, Galetti 1993, Wirminghaus et al. 2002, Boyes \& Perrin 2010)

- E: Other (Diamond \& Bond 1991, Schwing 2010).

\section{Landmarks and procedures}

The variation of cranial morphology is analysed using landmark-based geometric morphometry. In our former study, we used conventional morphometric variables, which were selected a priori (Pecsics et al. 2017). In this case, the meaningful variables are discovered by the analysis that was performed in previous studies (Pecsics et al. 2018, 2019). 
Table 1. Number and description of landmarks (terminology according to Baumel 1993, Sun et al. 2018)

1. táblázat Az egyes landmarkok száma és leírása (terminológia Baumel 1993 és Sun et al. 2018 alapján)

\begin{tabular}{|c|l|}
\hline Number of landmark & \multicolumn{1}{c|}{ Description of landmark } \\
\hline 1 & tip of the maxilla \\
\hline 2 & the lateral associating point of palatine and maxilla \\
\hline 3 & the most anterior-lateral point of pars lateralis \\
\hline 4 & the most posterior-lateral point of pars lateralis \\
\hline 5 & processus pterygoideus of palatine \\
\hline 6 & articulation point of palatine and maxilla \\
\hline 7 & articulation point pf pterygoid and quadrate \\
\hline 8 & most caudal point of the maxilla \\
\hline 9 & articulation of quadrate and jugal \\
\hline 10 & most lateral point of opisthotic \\
\hline 11 & most caudal point of condylus occipitalis \\
\hline 12 & most caudal point of foramen magnum \\
\hline 13 & prominentia cerebellaris \\
\hline
\end{tabular}

We tried to find landmarks for this analysis to cover the geometric form of the skull. The landmarks provide a comprehensive sampling of morphology and the features of biological significance can be explored. Ideal landmarks are discrete and noticeable anatomical features that do not alter their topological positions, providing adequate coverage of the morphology (Zelditch et al. 2004). The landmarks were taken from high resolution $(1200 \times 1600$ pixels) photos. We took 3 photographs from each specimen (lateral, ventral, and dorsal) with closed jaws and without the lower jaw. Images were standardised for the foramen magnum occipitale and the tip of the mandible. We investigated the repeatability of the measurements by Spearman's correlation. The test was between two separate digital measures performed on skull photos $(n=20)$. For each specimen, 13 fixed landmarks (Table 1) were recorded in ventral view (Guangdi et al. 2015, Sun et al. 2018). We used 800 sliding landmarks to examine the shape of the whole skull in dorsal and lateral view (Figure 1). These landmarks were allowed to slide along their corresponding curve due to the minimization of the bending energy. The coordinates of the landmarks were digitised using TpsDig 2.16 software (Rohlf 2010) and were transformed using the Procrustes superimposition method. Consensus configurations and relative warps were conducted. Variability in shape was assessed using the scores obtained for each individual on the first two relative warps. We conducted principal component analyses (PCA) on these morphological variables. The relative warps correspond to the principal components (PCs) and define the shape space in which individuals are replaced. We used PAST v.1.7 software (Hammer et al. 2001) to perform the principal component analysis and extract deformation grids. We only considered those PCs which explain $>10 \%$ of the variance. 


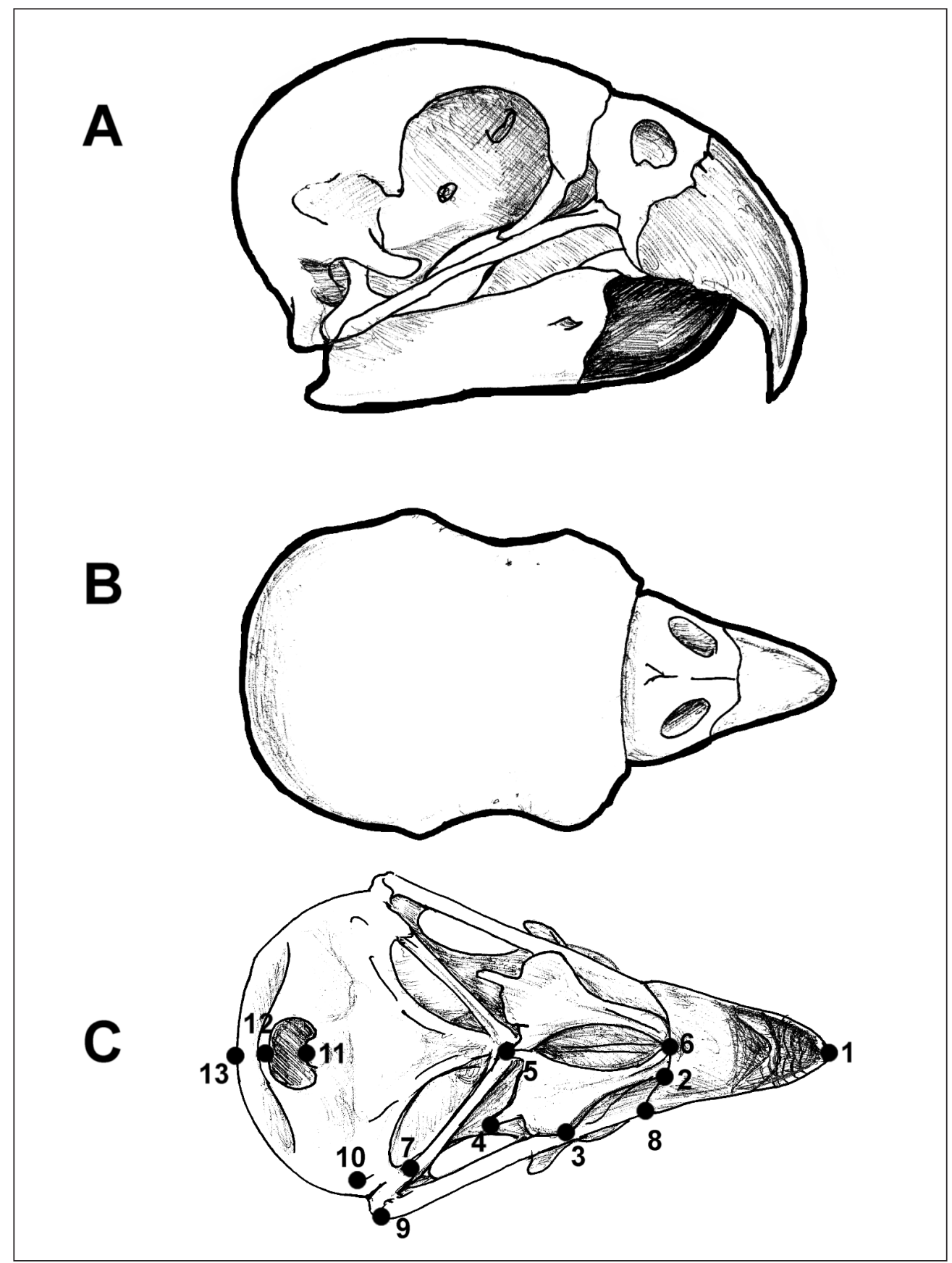

Figure 1. Position and number of landmarks. A: whole skull shape in lateral view, B: whole skull shape in dorsal view, $C$ : the shape fixed landmarks in ventral view (numbers correspond to Table 1)

1. ábra A vizsgálatban használt landmarkok száma és pozíciója. A: a teljes koponya oldalnézetből, B: a teljes koponya felülnézetből, C: fix landmarkok alulnézetből (a számok megnevezését lásd a 1. táblázatban) 


\section{Results}

Our measures were repeatable, irrespective of measuring mode (all $r>0.98$, all $P<0.001$ ). The first analysis focused on the whole skull from lateral view (Figure 2). We used sliding landmarks (800) to describe the cranial shape of the parrots. The first three PCs explained $38 \%, 23 \%$ and $14 \%$ of the variance in skull shape. The first PC axis described the relative height of the cranium (PC1). The macaw species have robust heads with relatively high and massive beaks, while lories and lorikeets have relatively longer and slender skulls with short and delicate beaks. The second and third PC axes described the relative length and curvature of the beak (PC2 and PC3). Species like Barred Parakeet (Bolborhynchus lineola), Turquoise Parrot (Neophema pulchella) and Red-headed Lovebird (Agapornis pullarius) have very short and curved beaks. The Kea (Nestor notabilis) and Slender-billed Parakeet (Enicognathus leptorhynchus) are bearing a long, narrow, and slender beak. True parrots and cockatoos share similar morphology (Figure 3).

During the second analysis, we used sliding landmarks (800) to describe the skull in dorsal view. The first two PCs explained $51 \%$ and $17 \%$ of the variance in shape (Figure 4). The first PC axis described variation in the relative length of the beak (PC1). The Red-shouldered Macaw (Diopsittaca nobilis) and Australian King-parrot (Alisterus scapularis) have relatively big neurocranium and shorter beaks compared with Kea (Nestor notabilis) and Slender-billed Parakeet (Enicognathus leptorhynchus). The second PC axis (PC2) described differences in the orientation and curvature of the lacrimal bone and the upper margin of orbits (Figure 4).

For the third analysis, we used fixed landmarks (13) to describe the shape of the cranium in dorsal view. The first two PCs explained $48 \%$ and $16 \%$ of the variance in shape. The first $\mathrm{PC}$ axis described the size and position of the palatine bone (PC1). The second $\mathrm{PC}$ axis reflected the relative width of the cranium and variation in the relative size of the neurocranium compare to the viscerocranium (PC2) (Figure 5).

In every case, the generalists are in the middle of the morphospace. We tried to fix the skulls in a standard position to minimize the impact of cranial kinesis (Figure 6).

Except Kea - which is bearing very unique skull attributes - there are no clear differences between taxonomic groups and the species are overlapping in the morphospace.

\section{Discussion}

The first analysis resulted differences in the relative height of the cranium and the beak in lateral view. Larger species usually have larger beaks compared to the neurocranium. The macaw species have robust heads with high and massive beaks. The Hyacinth Macaw (Anodorhynchus hyacinthinus) and the Palm Cockatoo (Probosciger aterrimus) have strong beaks; these species are able to crack hard food items, like nuts of pods and coconuts. The Alexandrine Parakeet (Psittacula eupatria) shares similar morphological attributes to the Scarlet Macaw (Ara macao). The shape of the skull of the macaw species strongly differs from the skull of small lorikeets (e.g. Charmosyna pulchella) and small hanging parrots (e.g. Loriculus vernalis). 


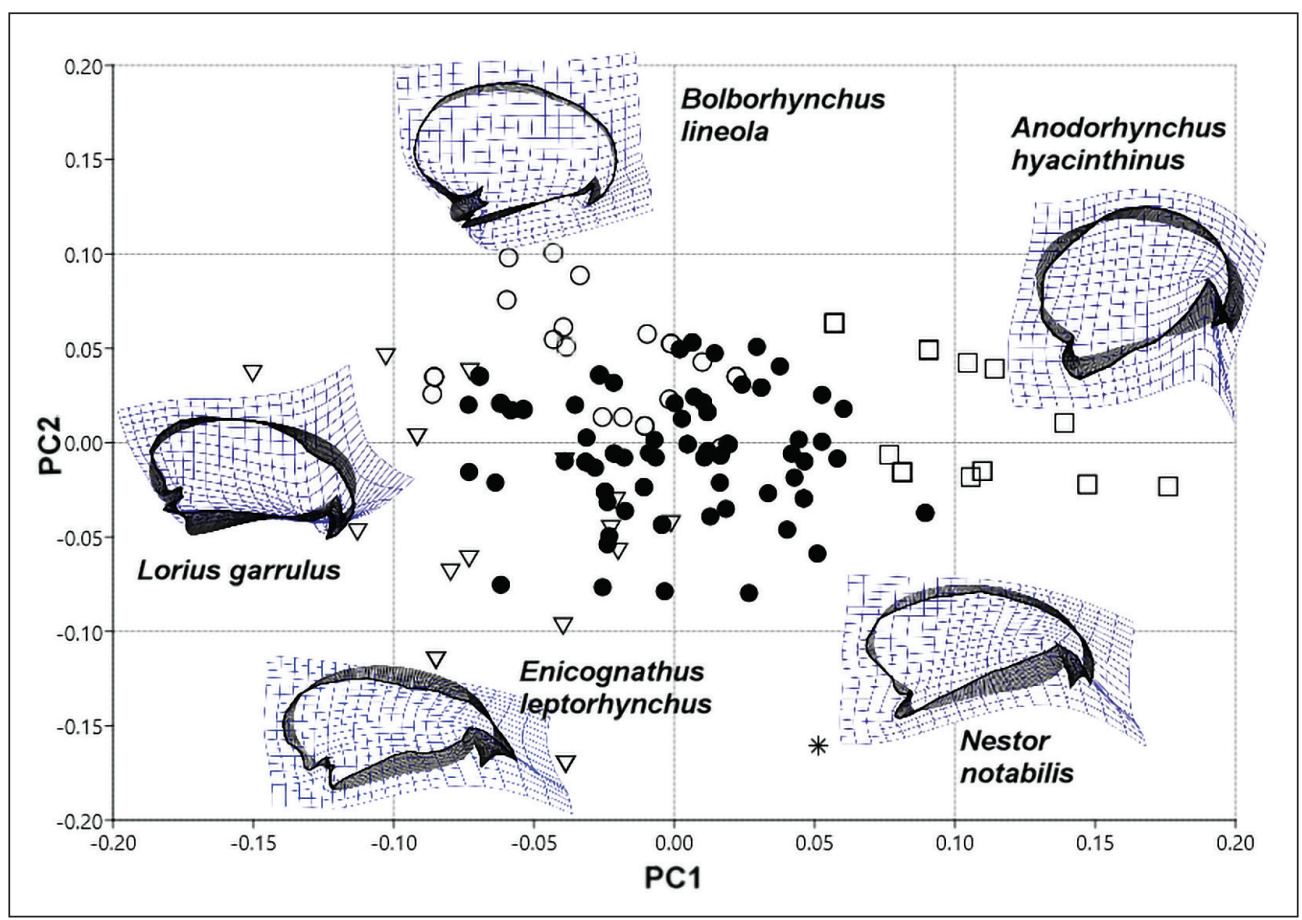

Figure 2. Graphical output of PCA performed on the two-dimensional landmark data (lateral view). PC1-PC2 biplot. The first PC axis described the relative height of the cranium (PC1). The second $P C$ axis described the relative length and curvature of the beak (PC2). Thick black areas show the differences compared to the computer generated mean shape

- Generalists, $\nabla$ Nectarine, soft food item eaters, $\square$ Big and rough food item eaters, $\circ$ Predominantly seed eaters, * Other

2. ábra A PCA grafikus megjelenítése kétdimenziós landmark adatok alapján (oldalnézet). Az első főtengely a koponya relatív magasságát magyarázza (PC1). A második főtengely a csőr relatív hosszúságával és görbületével hozható kapcsolatba (PC2). A fekete, vastagított terület a komputergenerált átlagformától való eltérést mutatja

- Generalisták, $\nabla$ Nektár és lágy táplálékot fogyasztók, $\square$ Nagy és kemény táplálékot fogyasztók, ○ Elsődlegesen magevők, * Egyéb

Allometry can explain some of the differences between species because the smaller species usually have bigger neurocranium and smaller viscerocranium (Grant et al. 1985). Although Pesquet's Parrot (Psittrichas fulgidus) has a large body size, it has a similar skull shape to lories, possibly caused by its highly specialized diet (Pryor et al. 2001). Species like Barred Parakeet (Bolborhynchus lineola), Turquoise Parrot (Neophema pulchella) and Red-headed Lovebird (Agapornis pullarius) have very short and curved beaks for extracting the edible part of the seeds. The strong and tapered beak is in positive correlation with bite performance (Van der Meij \& Bout 2004, Herrel et al. 2005). With its long, narrow, and slender beak, the Kea (Nestor notabilis) digs grubs from rotten logs and roots from the ground (O'Hara et al. 2012). This shape has a significant role in the development of extractive foraging techniques. This species has extremely broad diet and there 


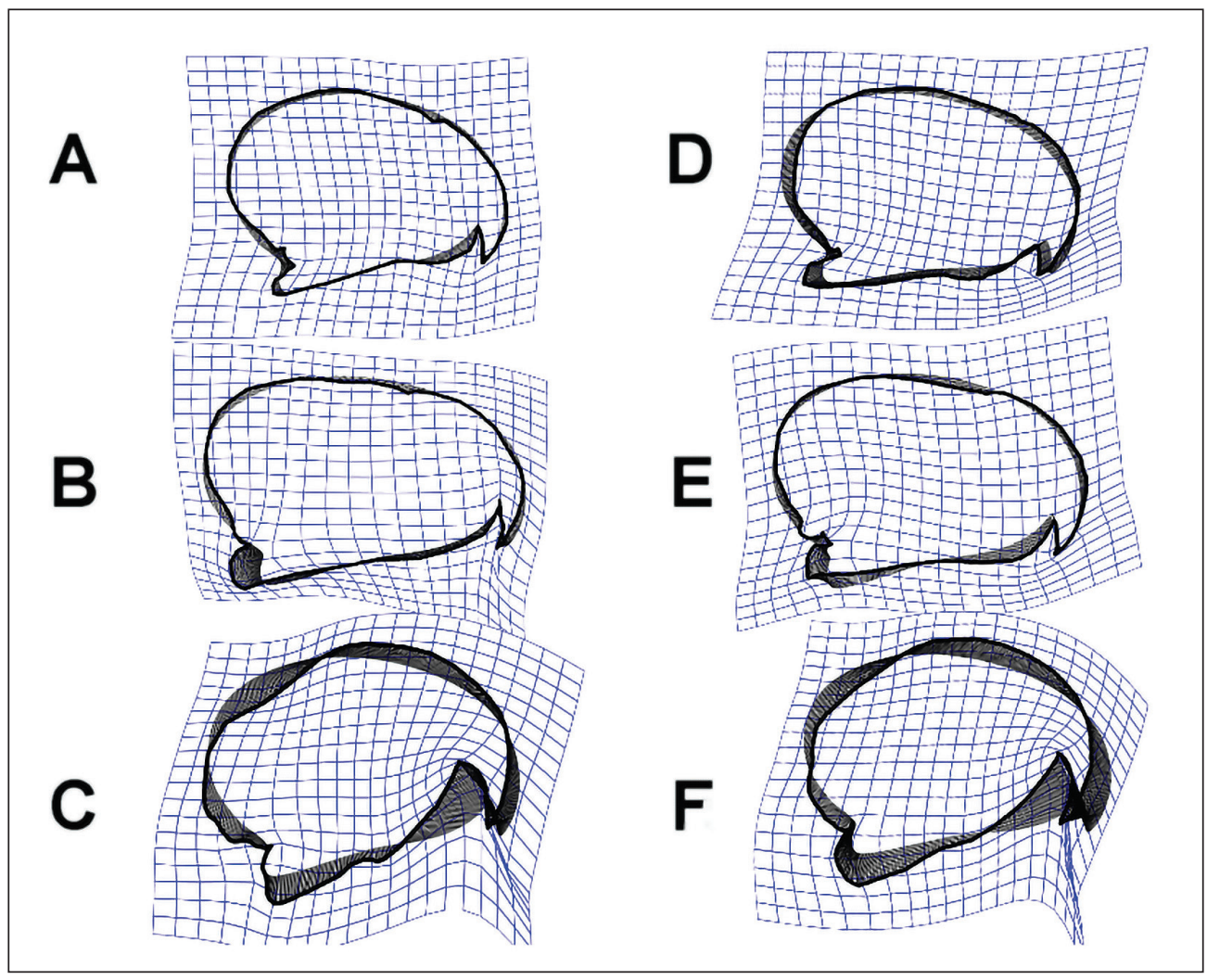

Figure 3. Various cockatoo and parrot species sharing convergent attributes. A: Cockatiel (Nymphicus hollandicus), B: Pale-headed Rosella (Platycercus adscitus), C: Yellow-crested Cockatoo (Cacatua sulphurea), D: Cuban Amazon (Amazona leucocephala), E: Palm Cockatoo (Probosciger aterrimus), F: Hyacinth Macaw (Anodorhynchus hyacinthinus)

3. ábra Az egyes kakaduk és papagájok hasonló konvergens bélyegeket hordoznak. A: Nimfapapgáj (Nymphicus hollandicus), B: Sápadtfejü rozella (Platycercus adscitus), C: Aranyosarcú kakadu (Cacatua sulphurea), D: Kubai amazon (Amazona leucocephala), E: Pálmakakadu (Probosciger aterrimus), F: Jácintkék ara (Anodorhynchus hyacinthinus)

are relatively subtle morphological differences between individuals and the noticeable intraspecific variation in the foraging ecology. It is clear that bill and head morphology is related to diet in this species (Greer 2015). Slender-billed Parakeet (Enicognathus leptorhynchus) - like other parrots - is an intelligent species, which likely promotes its persistence in dynamic landscapes. These characteristics may facilitate the adaptation of foraging behaviour to include most available resources within a given area (Carneiro et al. 2012). An overall increased bill length may improve the power or efficiency with which these species can rip off mud and flowers, extract grubs from live wood, or demolish decaying wood. Slender beaks allow the bird to deftly collect small food items from difficult to reach places.

The second analysis showed variety in the relative size of the neurocranium and viscerocranium like in the first analysis. Seed eaters and the species foraging on rough food 


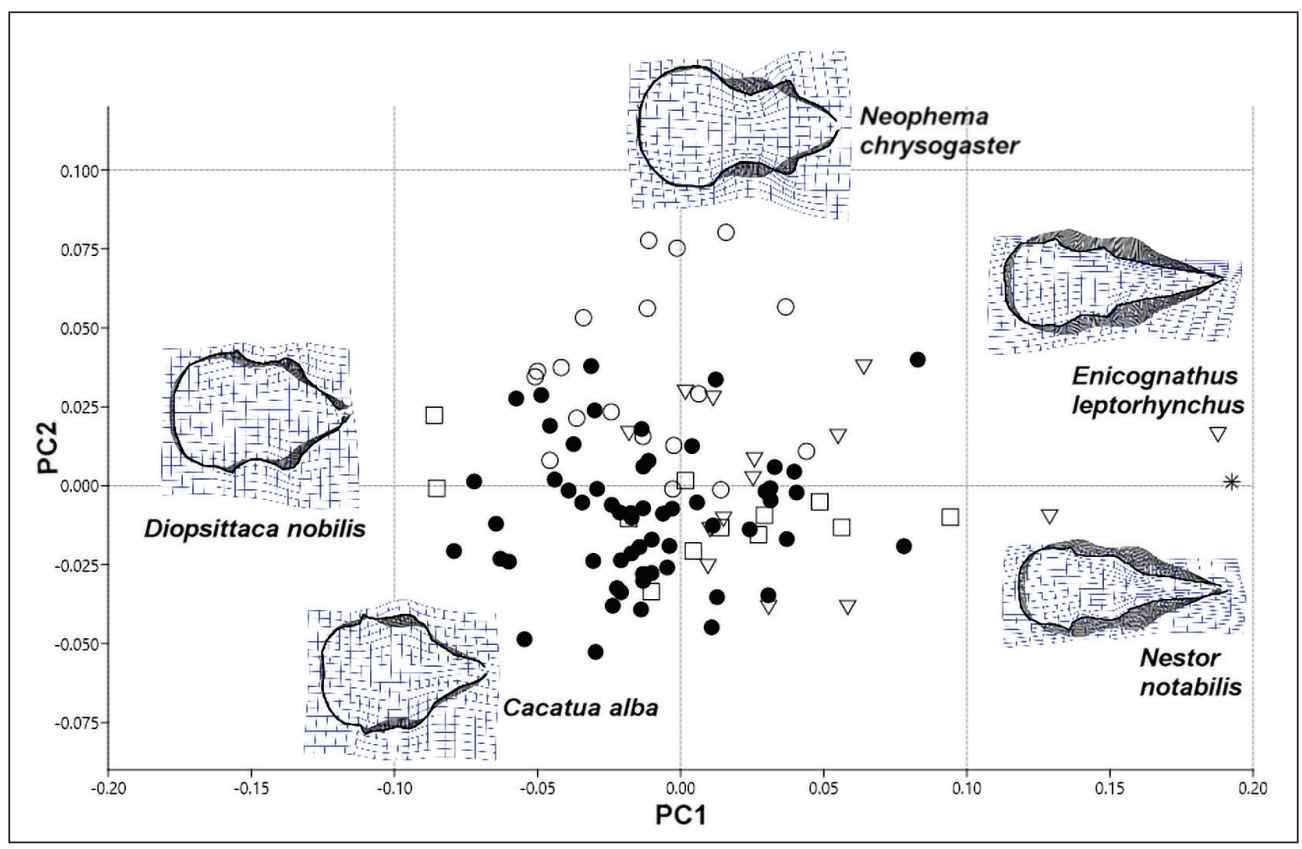

Figure 4. Graphical output of PCA performed on the two-dimensional landmark data (dorsal view). PC1-PC2 biplot. The first PC axis described variation in the relative length of the beak (PC1). The second $\mathrm{PC}$ axis (PC2) described differences in the orientation and curvature of the lacrimal bone and the upper margin of orbits. Thick black areas show the differences compared to the computer generated mean shape

- Generalists, $\nabla$ Nectarine, soft food item eaters, $\square$ Big and rough food item eaters, $\circ$ Predominantly seed eaters, * Other

4. ábra A PCA grafikus megjelenítése kétdimenziós landmark adatok alapján (felülnézet). Az első főtengely ( $\mathrm{PC} 1)$ a csőr relatív hosszúságát, a második fötengely a könnycsont relatív helyzetét és a szemüreg felső részének görbületét magyarázza. A fekete, vastagított terület a komputergenerált átlagformától való eltérést mutatja

- Generalisták, $\nabla$ Nektár és lágy táplálékot fogyasztók, $\square$ Nagy és kemény táplálékot fogyasztók, ○ Elsődlegesen magevők, * Egyéb

material usually have shorter tapered beak. In this analysis, the Kea and the Slender-billed Parakeet showed extreme differences with their elongated beak. The feeding categories are highly overlapping in the morphospace, but in dorsal view the curvature and the height of the beak is non-qualifiable. This analysis also showed differences in the curvature of the upper margin of the orbits. Cockatoo (Cacatua sp.) species have broad skulls and the increased distance between the orbits at the line of frontal bone. Australasian cockatoos have pronounced ossified periorbital structures. These birds have a well-developed suborbital arch and musculus pseudomasseter (Homberger 2017). At the postorbital region, the neurocranium showed a concave surface to the musculus adductor mandibulae externus. The amazon parrots (Amazona sp.) share similar attributes like cockatoos. Red-rumped Parrot (Psephotus haematonotus) and grass parrots (Neophema sp.) showed differences in the morphospace. These seed eaters have different skull structures. The frontal region 


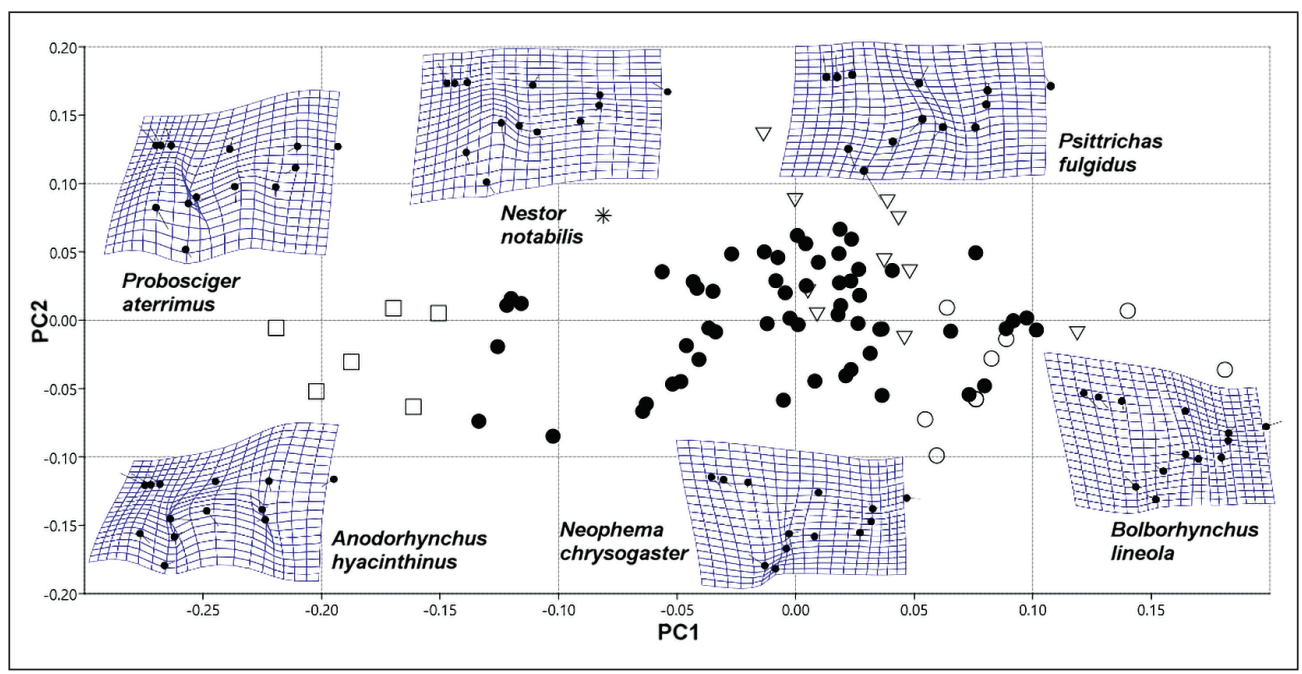

Figure 5. Graphical output of PCA performed on the two-dimensional landmark data (ventral view). PC1-PC2 biplot. The first PC axis described variation the size and position of the palatine bone (PC1). The second PC axis reflected to the relative width of the cranium and variation in the relative size of the neurocranium compare to the viscerocranium (PC2). Thick black areas show the differences compared to the computer generated mean shape

- Generalists, $\nabla$ Nectarine, soft food item eaters, $\square$ Big and rough food item eaters, $\circ$ Predominantly seed eaters, * Other

5. ábra A PCA grafikus megjelenítése kétdimenziós landmark adatok alapján (felülnézet). A PC tengelyek a palatinum relatív helyzetét és nagyságát (PC1), valamint a neurocranium és a visceroscranium relatív nagyságát mutatják (PC2). A fekete, vastagított terület a komputergenerált átlagformától való eltérést mutatja

- Generalisták, $\nabla$ Nektár és lágy táplálékot fogyasztók, $\square$ Nagy és kemény táplálékot fogyasztók, ○ Elsődlegesen magevők, * Egyéb

is narrower at the line of the orbits. The arboreal species have a wider, broad frontal region compared to those species which are mostly foraging on the ground. Arboreal species might use their beak more often as well as their feet to grip branches and haul themselves through the treetops.

The third analysis showed differences in the relative length of the cranium. Those species which are foraging on mechanically resistant food (e.g. macaw species and Palm Cockatoo) have a wider and more caudally positioned quadrate bone and foramen magnum occipitale. The palatine bone is extremely large with robust pterygoids. These structures support the surface in order to maximize the bite performance and the effectiveness of jaw closure muscles to crash nuts and hard-shelled seeds. These species have high skulls, which also correspond with the size of musculus ethmomandibularis. Several features enable parrots to exert strong bite forces during feeding and locomotion, including the strong adductor muscles that are evolutionary novelties in this group. The presence (or absence) and degree of development of these musculoskeletal structures are highly variable among different species (Burton 1974, Tokita 2003). Nectarivore parrots and the Pesquet Parrot generally have narrow skulls with slender quadrate bones and relatively 


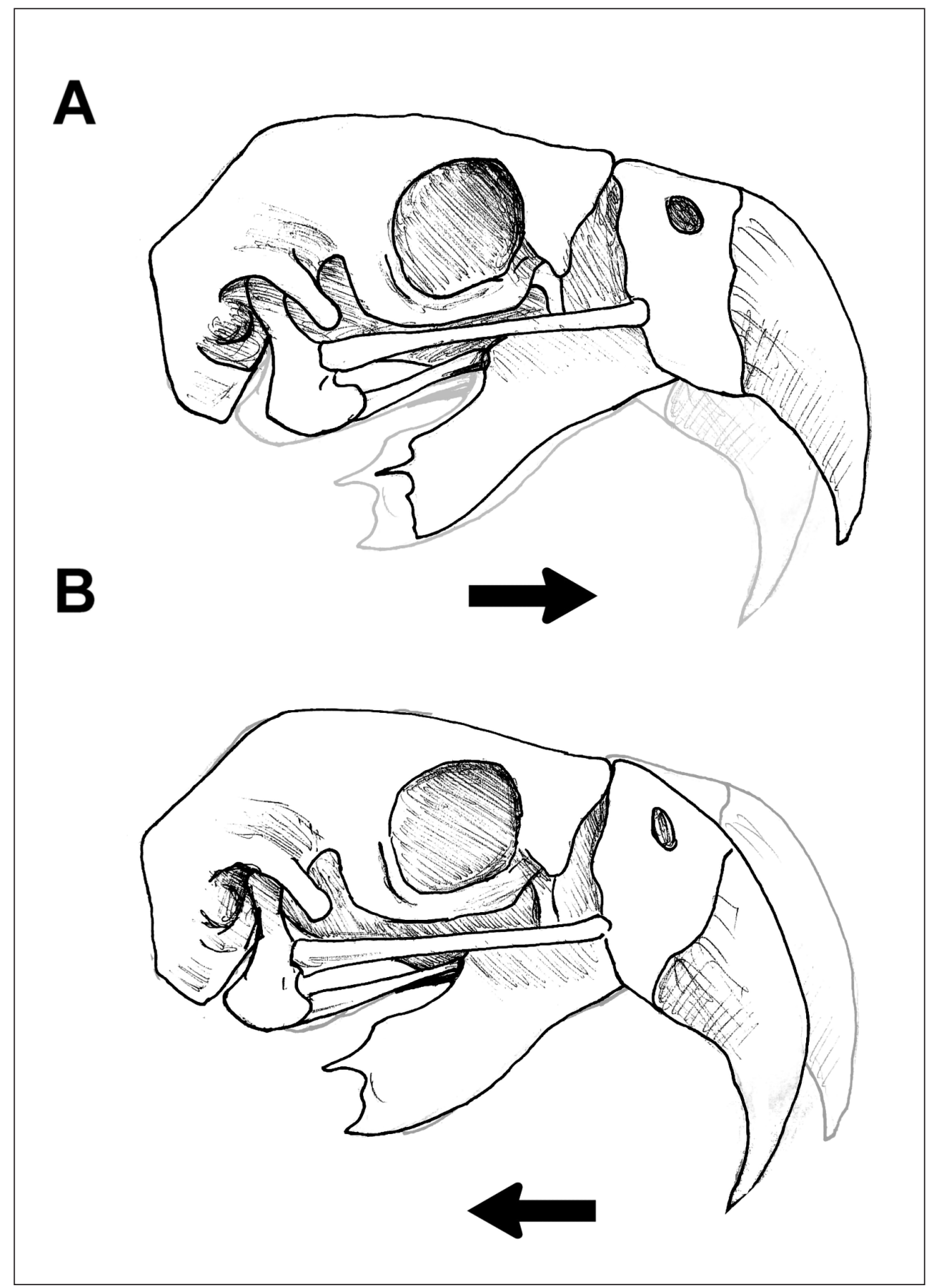

Figure 6. Kinesis of the cranium of a macaw with upper mandible raised (A), with upper mandible lowered (B)

6. ábra Kraniális kinezis egy ara példáján, a felső állkapocscsont felső (A) és alsó pozíciójában (B) 
gracile palatine and pterygoid bones. This indicates that these species have smaller and weaker pterygoid and adductor muscles. Lories and lorikeets have thinner and structurally weaker beaks than granivorous parrots of a similar size (Holyoak 1973). These lories constitute a highly nectarivorous parrot clade and their diet, associated with morphological innovation, allows them to explore underutilized niches and promote diversification (Schweizer et al. 2014). Seed eaters have relatively large neurocranium; the maxilla is short and wide. The quadrate bone is wide and positioned anteriorly and pterygoids are longer with broad and divided palatine bones. Bite force and speed of jaw closure perhaps play an important role. Cracking the seeds requires many fast, small, and precise movements in the oral cavity (Homberger 2017). Seed characteristics, size, and shape affected handling time with reference to bill structure (Hrabar \& Perrin 2002). Parrots occupy varied dietary niches that require an agile, mobilized feeding apparatus. Cranial kinesis flexibility among intracranial joints - has a central role in the unique feeding apparatus of this avian order. These birds possess a highly mobile, streptostylic quadrate by moving the rod-like pterygoids. The palatomaxillary system of articulation rotates the rostrum about the synovial craniofacial hinge, providing prokinetic movement between the frontal and nasal bones (Cost et al. 2017).

Our results show relationships between cranial attributes and diet preference, but also highlight the morphological complexity and dietary diversity of the feeding apparatus. Future studies reflecting on avian feeding apparatus may increase our knowledge and might be useful to understand the preferences of those species, which are threatened due to habitat loss. It would be interesting to perform combined analyses with cranial shape and attributes of the feet and hypotarsal structures to measure the differences between the arboreal species and those parrots which are conservatively feeding on grasslands. However numerous of species are sexually monomorphic (Miyaki et al. 1998), it is possible that there are species - e.g. the Great-billed Parrot (Tanygnathus megalorynchos) - where the sexual dimorphism might have role in the cranial shape, as it was observed previously in the case of the Kea (Bond et al. 1991). Similarities in the skull shape can reflect also the phylogenetic relation. In this study, we did not investigate the effect of phylogeny. The phylogenetic control would be necessary in a further analysis.

\section{Acknowledgements}

We are grateful to Péter Urtz for the technical assistance. The text was supervised by Bridgette Dennett, Emese Bodor and Jenő Nagy. 


\section{References}

Adams, D. C., Rohlf, F. J. \& Slice, D. E. 2004. Geometric morphometrics: ten years of progress following the 'revolution. - Italian Journal of Zoology 71(1): 5-16. DOI: 10.1080/11250000409356545

Anderson, R. A., McBrayer, L. D. \& Herrel, A. 2008. Bite force in vertebrates: opportunities and caveats for use of a nonpareil whole-animal performance measure. - Biological Journal of the Linnean Society 93(4): 709720. DOI: $10.1111 /$ j.1095-8312.2007.00905.x

Barker, F. K., Cibois, A., Schikler, P., Feinstein, J. \& Cracraft, J. 2004. Phylogeny and diversification of the largest avian radiation. - Proceedings of the National Academy of Sciences 101(30): 11040-11045. DOI: 10.1073/ pnas. 0401892101

Baumel, J. J. 1993. Handbook of avian anatomy: Nomina Anatomica Avium. - Publications of the Nuttall Ornithological Club (USA), no. 23.

Beggs, W. \& Mankelow, S. 2002. Kea (Nestor notabilis) make meals of Mice (Mus musculus). - Notornis 49: 50.

Benavidez, A., Palacio, F. X., Rivera, L. O., Echevarria, A. L. \& Politi, N. 2018. Diet of Neotropical parrots is independent of phylogeny but correlates with body size and geographical range. - Ibis 160(4): 742-754. DOI: 10.1111/ibi.12630

Benkman, C. W. 2003. Divergent selection drives the adaptive radiation of Crossbills. - Evolution 57(5): 11761181. DOI: $10.1111 / \mathrm{j} .0014-3820.2003 . t b 00326 . x$

Bond, A. B., Wilson, K. J. \& Diamond, J. 1991. Sexual dimorphism in the Kea Nestor notabilis. - Emu 91(1): 1219. DOI: $10.1071 /$ MU9910012

Boyes, R. S. \& Perrin, M. R. 2009. The feeding ecology of Meyer's Parrot Poicephalus meyeri in the Okavango Delta, Botswana. - Ostrich 80(3): 153-164. DOI: 10.2989/OSTRICH.2009.80.3.5.968

Boyes, R. S. \& Perrin, M. R. 2010. Aerial surveillance by a generalist seed predator: food resource tracking by Meyer's Parrot Poicephalus meyeri in the Okavango Delta, Botswana. - Journal of Tropical Ecology 26(4): 381-392. DOI: 10.1017/S0266467410000210

Bradbury, J. W. 2003. Vocal communication in wild parrots. - In: de Waal, F. B. M. \& Tyack, P. L. (eds.) Animal social complexity: Intelligence, culture, and individualized societies. - Harvard University Press, pp. 293-316.

Brejaart, R. 1988. Diet and feeding behaviour of the Kea (Nestor notabilis). - Unpublished Thesis, Lincoln College, Canterbury, New Zealand

Bright, J. A., Marugán-Lobón, J., Rayfield, E. J. \& Cobb, S. N. 2019. The multifactorial nature of beak and skull shape evolution in parrots and cockatoos (Psittaciformes). - BMC Evolutionary Biology 19(1): 104. DOI: 10.1186/s12862-019-1432-1

Bryant, S. L. 1994. Habitat and potential diet of the Ground Parrot in Tasmania. - Emu 94(3): 166-171.

Burton, P. J. K. 1974. Jaw and tongue features in Psittaciformes and other orders with special reference to the anatomy of the Tooth-billed Pigeon (Didunculus strigirostris). - Journal of Zoology 174(2): 255-276. DOI: 10.1111/j.1469-7998.1974.tb03156.x

Carneiro, A. P. B., Jiménez, J. E. \& White, Jr, T. H. 2012. Post-fledging habitat selection by the Slender-billed Parakeet (Enicognathus leptorhynchus) in a fragmented agricultural landscape of southern Chile. - The Condor 114(1): 166-172. DOI: 10.1525/cond.2011.100127

Carril, J., Tambussi, C. P., Degrange, F. J., Benitez Saldivar, M. J. \& Picasso, M. B. J. 2016. Comparative brain morphology of Neotropical parrots (Aves, Psittaciformes) inferred from virtual 3D endocasts. - Journal of Anatomy 229(2): 239-251. DOI: 10.1111/joa.12325

Christidis, L. \& Boles, W. 2008. Systematics and taxonomy of Australian birds. - Csiro Publishing

Christidis, L., Schodde, R., Shaw, D. D. \& Maynes, S. F. 1991. Relationships among the Australo-Papuan parrots, lorikeets, and cockatoos (Aves: Psittaciformes): protein evidence. - The Condor 93(2): 302-317. DOI: 10.1111/j.1474-919X.1991.tb04570.x

Clarke, C. M. H. 1971. Observations on Population, Movements and Food of the Kea (Nestor notabilis). - NZ Forest Service

Colwell, R. K. 2000. Rensch's rule crosses the line: convergent allometry of sexual size dimorphism in hummingbirds and flower mites. - American Naturalist 156: 495-510. DOI: 10.1086/303406

Cost, I. N., Middleton, K. M., Witmer, L. M., Echols, M. S. \& Holliday, C. M. 2017. Comparative anatomy and biomechanics of the feeding apparatus of Parrots (Aves: Psittaciformes). - The FASEB Journal 31(Suppl. 1): pp. 577.

Cracraft, J. 1973. Continental drift, paleoclimatology, and the evolution and biogeography of birds. - Journal of Zoology 169(4): 455-543. DOI: 10.1111/j.1469-7998.1973.tb03122.x 
Csermely, D., Bertè, L. \& Camoni, R. 1998. Prey killing by Eurasian Kestrels: the role of the foot and the significance of bill and talons. - Journal of Avian Biology 29(1): 10-16. DOI: 10.2307/3677335

Diamond, J. \& Bond, A. B. 1991. Social behavior and the ontogeny of foraging in the Kea (Nestor notabilis). - Ethology 88(2): 128-144.

Dumont, E. R. 2003. Bats and fruit: an ecomorphological approach. - In: Kunz, T. H. \& Fenton, M. B (eds.) Bat Ecology. - University of Chicago Press, Chicago, pp. 398-429.

Dyke, G. J. \& Mayr, G. 1999. Did parrots exist in the Cretaceous period? - Nature 399(6734): 317-318. DOI: $10.1038 / 20583$

Edgar, A. T. (ed.) 1974. Farewell Spit, March 1974. - Notornis 21: 250-259.

Elliott, T. F., Jusino, M. A., Trappe, J. M., Lepp, H., Ballard, G. A., Bruhl, J. J. \& Vernes, K. 2019. A global review of the ecological significance of symbiotic associations between birds and fungi. - Fungal Diversity 1-34. DOI: 10.1007/s13225-019-00436-3

Fabbri, M., Koch, N. M., Pritchard, A. C., Hanson, M., Hoffman, E., Bever, G. S., Balanoff, A. M., Morris, Z. S., Field, D. J., Camacho, J., Rowe, T. B., Norell, M. A., Smith, R. M., Abzhanov, A. \& Bhullar, B-A. S. 2017. The skull roof tracks the brain during the evolution and development of reptiles including birds. Nature Ecology \& Evolution 1(10): 1543-1550. DOI: 10.1038/s41559-017-0288-2

Forshaw, J. M. 2010. Parrots of the World (Vol. 70). - Princeton University Press

Galetti, M. 1993. Diet of the Scaly-headed Parrot (Pionus maximiliani) in a semideciduous forest in southeastern Brazil. - Biotropica 25(4): 419-425. DOI: 10.2307/2388865

Galetti, M. \& Rodrigues, M. 1992. Comparative seed predation on pods by parrots in Brazil. - Biotropica 24(2): 222-224. DOI: $10.2307 / 2388679$

Grant, P. R., Abbott, I., Schluter, D., Curry, R. L. \& Abbott, L. K. 1985. Variation in the size and shape of Darwin's finches. - Biological Journal of the Linnean Society 25(1): 1-39. DOI: 10.1111/j.1095-8312.1985. tb00384.x

Greer, A. L. 2015. Intraspecific variation in the foraging ecology and morphology of Kea Nestor notabilis. A thesis submitted in partial fulfilment of the requirement for the Degree of Doctor of Philosophy in Ecology. University of Canterbury, Christchurch, New Zealand

Guangdi, S. I., Dong, Y., Ma, Y. \& Zhang, Z. 2015. Shape similarities and differences in the skulls of scavenging raptors. - Zoological Science 32(2): 71-177. DOI: 10.2108/zs130253

Hackett, S. J., Kimball, R. T., Reddy, S., Bowie, R. C., Braun, E. L., Braun, M. J. \& Huddleston, C. J. 2008. A phylogenomic study of birds reveals their evolutionary history. - Science 320(5884): 1763-1768. DOI: 10.1126/science. 1157704

Hammer, Ø., Harper, D. A. T. \& Ryan, P. D. 2001. PAST: paleontological statistics software package for education and data analysis. - Palaeontologia Electronica 4: 1-9.

Herrel, A., Podos, J., Huber, S. K. \& Hendry, A. P. 2005. Bite performance and morphology in a population of Darwin's finches: implications for the evolution of beak shape. - Functional Ecology 19(1): 43-48. DOI: 10.1111/j.0269-8463.2005.00923.x

Holyoak, D. T. 1973. Comments on taxonomy and relationships in the parrot subfamilies Nestorinae, Loriinae and Platycercinae. - Emu 73(4): 157-176. DOI: 10.1071/MU973157

Homberger, D. G. 2006. Classification and status of wild populations of parrots. - Manual of parrot behavior. - Ames (IA): Blackwell Publishing, pp. 3-11.

Homberger, D. G. 2017. The avian lingual and laryngeal apparatus within the context of the head and jaw apparatus, with comparisons to the mammalian condition: functional morphology and biomechanics of evaporative cooling, feeding, drinking, and vocalization. - In: Maina, J. N. (ed.) The biology of the avian respiratory system. - Springer, Cham, pp. 27-97. DOI: 10.1007/978-3-319-44153-5_2

Hrabar, H. D. K. \& Perrin, M. 2002. The effect of bill structure on seed selection by granivorous birds. - African Zoology 37(1): 67-80. DOI: 10.1080/15627020.2002.11657157

Iwaniuk, A. N., Dean, K. M. \& Nelson, J. E. 2005. Interspecific allometry of the brain and brain regions in parrots (Psittaciformes): comparisons with other birds and primates. - Brain, Behavior and Evolution 65(1): 40-59. DOI: $10.1159 / 000081110$

Janzen, D. H. 1969. Seed-eaters versus seed size, number, toxicity and dispersal. - Evolution 23(1): 1-27. DOI: 10.1111/j.1558-5646.1969.tb03489.x

Jarvis, E. D., Mirarab, S., Aberer, A. J., Li, B., Houde, P., Li, C., Ho, S. Y. W., Faircloth, B. C., Nabholz, B., Howard, J. T., Suh, A. et al. \& Zhang, G. 2014. Whole-genome analyses resolve early branches in the tree of life of modern birds. - Science 346(6215): 1320-1331. DOI: 10.1126/science.1253451 
Provost, K. L., Joseph, L. \& Smith, B. T. 2018. Resolving a phylogenetic hypothesis for parrots: implications from systematics to conservation. - Emu 118(1): 7-21. DOI: 10.1080/01584197.2017.1387030

Kulemeyer, C., Asbahr, K., Gunz, P., Frahnert, F. \& Bairlein, F. 2009. Functional morphology and integration of corvid skulls-a 3D geometric morphometric approach. - Frontiers of Zoology 6(1): 2. DOI: 10.1186/1742-9994-6-2

Lee, A. T., Brightsmith, D. J., Vargas, M. P., Leon, K. Q., Mejia, A. J. \& Marsden, S. J. 2014. Diet and geophagy across a western Amazonian parrot assemblage. - Biotropica 46(3): 322-330. DOI: 10.1111/btp.12099

Lill, A. 2009. Food resources and urban colonisation by lorikeets and parrots. - Victorian Naturalist 126(3): 70-72.

Marriner, G. R. 1908. The Kea: A New Zealand Problem: Including a Full Description of this Very Interesting Bird, Its Habitat and Ways, Together with a Discussion of the Theories Advanced to Explain Its Sheep-killing Propensities. - Marriner Bros

Marugán-Lobón, J. \& Buscalioni, Á. D. 2006. Avian skull morphological evolution: exploring exo- and endocranial covariation with two-block partial least squares. - Zoology 109(3): 217-230. DOI: 10.1016/j. zool.2006.03.005

Mayr, G. 2010. Parrot interrelationships-morphology and the new molecular phylogenies. - Emu 110(4): 348357. DOI: $10.1071 / \mathrm{MU} 10035$

Mayr, G., Rana, R. S., Rose, K. D., Sahni, A., Kumar, K. \& Smith, T. 2013. New specimens of the early Eocene bird Vastanavis and the interrelationships of stem group Psittaciformes. - Paleontological Journal 47(11): 1308-1314.

McBrayer, L. D. 2004. The relationship between skull morphology, biting performance and foraging mode in Kalahari lacertid lizards. - Zoological Journal of the Linnean Society 140(3): 403-416. DOI: 10.1111/j.10963642.2003.00106.x

McCormack, J. E., Harvey, M. G., Faircloth, B. C., Crawford, N. G., Glenn, T. C. \& Brumfield, R. T. 2013. A phylogeny of birds based on over 1,500 loci collected by target enrichment and high-throughput sequencing. PLoS One 8(1): e54848. DOI: 10.1371/journal.pone.0054848

McInnes, R. S. \& Carne, P. B. 1978. Predation of cossid moth larvae by Yellow-tailed Black Cockatoos causing losses in plantations of Eucalyptus grandis in north coastal New South Wales. - Wildlife Research 5(1): 101-121.

Miyaki, C. Y., Griffiths, R., Orr, K., Nahum, L. A., Pereira, S. L., \& Wajntal, A. 1998. Sex identification of parrots, toucans, and curassows by PCR: perspectives for wild and captive population studies. Zoo Biology: Published in affiliation with the American Zoo and Aquarium Association 17(5): 415-423.

O’Hara, M., Gajdon, G. K. \& Huber, L. 2012. Kea logics: how these birds solve difficult problems and outsmart researchers. - Logic and Sensibility 5: 23-38.

Pecsics, T., Laczi, M., Nagy, G. \& Csörgö, T. 2017. The cranial morphometrics of the wildfowl (Anatidae). - Ornis Hungarica 25(1): 44-57. DOI: 10.1515/orhu-2017-0004

Pecsics, T., Laczi, M., Nagy, G., Kondor, T. \& Csörgő, T. 2018. Analysis of skull morphometric characters in Owls (Strigiformes). - Ornis Hungarica 26(1): 41-53. DOI: 10.1515/orhu-2018-0003

Pecsics, T., Laczi, M., Nagy, G., Kondor, T. \& Csörgö, T. 2019. Analysis of skull morphometric characters in diurnal raptors (Accipitriformes and Falconiformes). - Ornis Hungarica 27(1): 117-131. DOI: 10.2478/ orhu-2019-0008

Pizo, M. A., Simáo, I. \& Galetti, M. 1995. Diet and flock size of sympatric parrots in the Atlantic forest of Brazil. - Ornitologia Neotropical 6: 87-95.

Prum, R. O., Berv, J. S., Dornburg, A., Field, D. J., Townsend, J. P., Lemmon, E. M. \& Lemmon, A. R. 2015. A comprehensive phylogeny of birds (Aves) using targeted next-generation DNA sequencing. - Nature 526(7574): 569-573. DOI: 10.1038/nature15697

Pryor, G. S., Levey, D. J., Dierenfeld, E. S. \& Bosque, C. 2001. Protein requirements of a specialized frugivore, Pesquet's Parrot (Psittrichas fulgidus). - The Auk 118(4): 1080-1088. DOI: 10.1093/auk/118.4.1080

Ragusa-Netto, J. \& Fecchio, A. 2006. Plant food resources and the diet of a parrot community in a gallery forest of the southern Pantanal (Brazil). - Brazilian Journal of Biology 66(4): 1021-1032. DOI: 10.1590/S151969842006000600008

Rand, A. L. 1942. Results of the Archbold Expeditions, No. 43. Birds of the 1938-1939 New Guinea expedition. - Bulletin of the American Museum of Natural History 79: 425-516.

Renton, K. 2001. Lilac-crowned Parrot diet and food resource availability: resource tracking by a parrot seed predator. - The Condor 103(1): 62-69. DOI: 10.1093/condor/103.1.62

Renton, K., Salinas-Melgoza, A., De Labra-Hernández, M. Á. \& de la Parra-Martínez, S. M. 2015. Resource requirements of parrots: nest site selectivity and dietary plasticity of Psittaciformes. - Journal of Ornithology 156(1): 73-90. DOI: 10.1007/s10336-015-1255-9 
Rohlf, F. J. 2010. TpsDig, version 2.16. - Department of Ecology and Evolution, State University of New York, Stony Brook, USA

Schweizer, M., Güntert, M., Seehausen, O., Leuenberger, C. \& Hertwig, S. T. 2014. Parallel adaptations to nectarivory in parrots, key innovations and the diversification of the Loriinae. - Ecology and Evolution 4(14): 2867-2883. DOI: 10.1002/ece3.1131

Schwing, R. 2010. Scavenging behaviour of Kea (Nestor notabilis). - Notornis 57(2): 98-99.

Sun, Y., Si, G., Wang, X., Wang, K. \& Zhang, Z. 2018. Geometric morphometric analysis of skull shape in the Accipitridae. - Zoomorphology 137: 445-456. DOI: 10.1007/s00435-018-0406-y

Sustaita, D. \& Hertel, F. 2010. In vivo bite and grip forces, morphology and prey-killing behavior of North American accipiters (Accipitridae) and falcons (Falconidae). - Journal of Experimental Biology 213(15): 2617-2628. DOI: $10.1242 /$ jeb.041731

Temple, P. 1996. The book of the Kea. - Auckland: Hodder Moa Becket

Terborgh, J., Robinson, S. K., Parker III., T. A., Munn, C. A. \& Pierpont, N. 1990. Structure and organization of an Amazonian forest bird community. - Ecological Monographs 60(2): 213-238. DOI: 10.2307/1943045

Tokita, M. 2003. The skull development of parrots with special reference to the emergence of a morphologically unique cranio-facial hinge. - Zoological Science 20(6): 749-758. DOI: 10.2108/zsj.20.749

Tokita, M. 2006. Cranial neural crest cell migration in Cockatiel Nymphicus hollandicus (Aves: Psittaciformes). - Journal of Morphology 267(3): 333-340. DOI: 10.1002/jmor.10408

Tokita, M. \& Nakayama, T. 2014. Development of the trigeminal motor neurons in parrots: Implications for the role of nervous tissue in the evolution of jaw muscle morphology. - Journal of Morphology 275(2): 191-205. DOI: $10.1002 /$ jmor.20208

Tokita, M., Kiyoshi, T. \& Armstrong, K. N. 2007. Evolution of craniofacial novelty in parrots through developmental modularity and heterochrony. - Evolution \& Development 9(6): 590-601. DOI: 10.1111/j.1525142X.2007.00199.x

Van der Meij, M. A. A. \& Bout, R. G. 2004. Scaling of jaw muscle size and maximal bite force in finches. - Journal of Experimental Biology 207(16): 2745-2753. DOI: 10.1242/jeb.01091

Vaughan, C., Nemeth, N. \& Marineros, L. 2006. Scarlet Macaw, Ara macao (Psittaciformes: Psittacidae) diet in Central Pacific Costa Rica. - Revista de Biología Tropical 54(3): 919-926.

Ward, A. B., Weigl, P. D. \& Conroy, R. M. 2002. Functional morphology of raptor hindlimbs: implications for resource partitioning. - The Auk 119(4): 1052-1063.

Waterhouse, D. M. 2006. Parrots in a nutshell: the fossil record of Psittaciformes (Aves). - Historical Biology 18(2): 227-238. DOI: 10.1080/08912960600641224

Wirminghaus, J. O., Downs, C. T., Symes, C. T. \& Perrin, M. R. 2002. Diet of the Cape Parrot, Poicephalus robustus, in afromontane forests in Kwazulu-Natal, South Africa. - Ostrich 73(1-2): 20-25. DOI: $10.2989 / 00306520209485347$

Wood, G. A. 1988. Further field observations of the Palm Cockatoo Probosciger aterrimus in the Cape York Peninsula, Queensland. - Corella 12: 48-52.

Zelditch, M., Swiderski, D., Sheets, D. H. \& Fink, W. 2004. Geometric Morphometrics for Biologists: A primer. - Elsevier Academic Press, Waltham, MA.

Zusi, R. L. 1993. Patterns of diversity in the avian skull. - In: Hanken, J. \& Hall, B. K. (eds.) The Skull, Vol. 2. Patterns of Structural and Systematic Diversity. - University of Chicago Press, Chicago, pp. 391-437.

Zweers, G. A., Berkhoudt, H. \& Berge, J. V. 1994. Behavioral mechanisms of avian feeding. - In: Bels, V. L., Chardon, M. \& Vandewalle, P. (eds.) Biomechanics of feeding in vertebrates. - Springer, Berlin, Heidelberg, pp. 241-279.

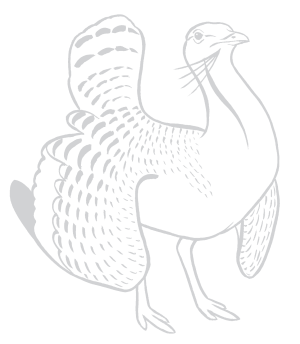

